\title{
Anthrovision
}

Vaneasa Online Journal

Vol. $7.1 \mid 2019$

Aesthetic Encounters

\section{Returning to Form: Anthropology, Art and a Trans- Formal Methodological Approach}

\section{Alex Flynn and Lucy Bell}

\section{(2) OpenEdition \\ Journals}

\section{Electronic version}

URL: http://journals.openedition.org/anthrovision/5001

DOI: 10.4000/anthrovision.5001

ISSN: 2198-6754

\section{Publisher}

VANEASA - Visual Anthropology Network of European Association of Social Anthropologists

\section{Electronic reference}

Alex Flynn and Lucy Bell, « Returning to Form: Anthropology, Art and a Trans-Formal Methodological Approach », Anthrovision [Online], Vol. 7.1 | 2019, Online since 11 March 2020, connection on 12 November 2020. URL : http://journals.openedition.org/anthrovision/5001 ; DOI : https://doi.org/ 10.4000/anthrovision.5001

This text was automatically generated on 12 November 2020 .

(C) Anthrovision 


\title{
Returning to Form: Anthropology, Art and a Trans-Formal Methodological Approach
}

\author{
Alex Flynn and Lucy Bell
}

1 This article focuses on cartonera publishers, small community-based collectives whose members make low-cost books from recovered materials in an explicit attempt to make both the consumption and production of literature accessible to wider society. Cartonera first emerged in Buenos Aires in the wake of the 2001 economic crisis, during which unemployment rates soared, leaving marginalised residents of the city to seek alternative means of supporting themselves and their families. Many took to the streets to become cartoneros ('waste pickers'), sorting through the city's daily waste stream, picking out metal, glass, paper, and cardboard to sell for recycling.

In 2003, the founding members of the first cartonera collective, Washington Cucurto, Javier Barilaro and Fernanda Laguna, were determined to find alternative ways of publishing books. Their criteria were simple: first, the crisis had made establishing a conventional publishing operation financially impossible, so any production method had to be extremely low cost; and second, they were committed to selling as many books as possible at an affordable price, thus challenging the notion of books as an upper middle-class commodity. ${ }^{1}$ This commitment was not just a social gesture, of course, but a plastic artistic proposition that in itself recalls different literary traditions of popular printing, from cheap books to DIY-zines (Piepmeier 2009). In this, their key artistic influence was the Belleza y Felicidad collective, a printing press and gallery founded by Laguna and her friend Cecilia Pavón that, since the late 1990s, had been publishing simple texts in the form of stapled photocopies (Palmeiro 2011).

With these guiding principles, their press, Ediciones Eloisa, began production in Laguna's studio. What was unclear at the time, though, was how the counter-cultural, marginal and experimental texts that Ediciones Eloísa was publishing could find a broader connection to the social processes that were being practiced in the workspace. Laguna's studio in Almagro, like much of Buenos Aires, was on the route of many cartoneros, and 
these figures would often interact with readings and events that were constantly taking place. At this point, Cucurto suggested that in terms of readily available cheap materials, cardboard was the obvious resource to work with and the cartonero, the figure who best represented the crisis. Driven by personal connections and collaborations, the collective began buying cardboard from the cartoneros at five times its market value and production commenced of hand-painted, cardboard-bound books in collaboration with the waste-pickers (Epplin 2009). In this manner, bringing the social forms present in their location into dialogue with their aesthetic intentions, Ediciones Eloísa irrevocably became Eloísa Cartonera.

4 Since 2003, this model has spread rapidly across Latin America and beyond. There are over 250 cartonera collectives today from Buenos Aires to New York, from Paris to Maputo, from Seoul to Seville, each with a unique way of publishing books. What all cartonera practitioners share, however, is a strong sense of collective belonging through the notion of cartonera, which refers to the publishers themselves and to the cardboardbound books that they publish, as well as referring back to the waste-pickers who first inspired Eloísa Cartonera. The adjective cartonera, in turn, encompasses a number of common aesthetic and social practices: cartonera books are all made by hand and bound with recovered cardboard, which is intervened through different artistic techniques, from painting and drawing to collage and serigraphy; cartonera editions have limited print runs (generally between 50 and 120), and are often numbered to highlight their uniqueness as art objects; and cartonera publishers work with minority groups or marginalized communities to create new social relations and communities through their social and aesthetic practices.

5 Cartonera's artistic proposition is thus deeply rooted in the social forms that these organisations have come to assume, creating a convergence of democratic politics and participatory aesthetics, literary forms and social formations. In this article, we put forward a methodological pathway for work between the social sciences and the humanities that is premised on this relation between social and aesthetic form. We focus on the ways these forms intersect and the implications this has for expanding an ethnographic methodology to capture the agency of different socio-aesthetic forms of production. We begin by describing in more detail Dulcinéia Catadora, a cartonera publisher based in São Paulo that will be the ethnographic focus of this article. The interconnectedness of Dulcinéia's location, production and practice is key to foreground, as is the impossibility, for the collective's members, of separating any one element from another. We then present three theoretical propositions by Jacques Rancière (2004, 2009), Néstor García Canclini (2014) and Caroline Levine (2015), which open up crucial theoretical and methodological pathways, enabling us to re-examine art, literature and aesthetics not in isolation from, but rather in relation to, social and political processes. From our distinct positionalities in social anthropology and literary/cultural studies we discuss the methodological journey upon which we embarked in response to the challenge posed to us by cartonera publishing: how can ethnographic practice intersect with aesthetics in a mode which goes beyond the illustrative? How might we reconsider the kinds of outputs that ethnographic methods generally produce? We conclude by proposing what we term a 'trans-formal' approach embedded within emulation, offering an ethnographic example of how we put this into practice. Such a framework, we suggest, offers the possibility of researching and experimenting with contemporary cultural practices - located at the interstices of art, society and politics - in a way that departs not only from a different understanding of 
the relationship between ethnography and aesthetics, but also opens up new possibilities for research that is multi-disciplinary, transnational, horizontal and participatory.

\section{Dulcinéia Catadora: Glicério}

6 Based in the Glicério recycling cooperative in São Paulo, the Dulcinéia collective is composed of Lúcia Rosa, an artist, and three waste-pickers from the cooperative itself: Andréia Emboava, Maria Dias da Costa and Eminéia dos Santos. Founded in 2007, Dulcinéia's poetry, prose and artists' books emerge from workshops run in the cooperative, from collaborations with artists, as well as through projects with community groups. However, while Dulcinéia has undertaken many projects within wider communities, it is rooted very specifically to the Glicério cooperative and Lúcia told us many times how it would be impossible to imagine Dulcinéia Catadora in a different space: 'The phenomenon was born with the catadores (waste-pickers in Brazilian Portuguese), and I never wanted to compromise on this, because I think this is the soul of Dulcinéia.'

7 This rootedness is striking given the practical difficulties in working from this location. Above the recycling coop traffic thunders down a four lane highway overpass, a constant flow on the Radial Leste, one of the principal arteries of the city. Every day refuse is brought here from all over the city, wheeled on hand pulled carts by members of the cooperative, the catadores, to be sifted, cleaned, sorted, crushed, packaged, and then sold on up the chain.

The Glicério recycling cooperative as seen from Dulcinéia Catadora's workshop

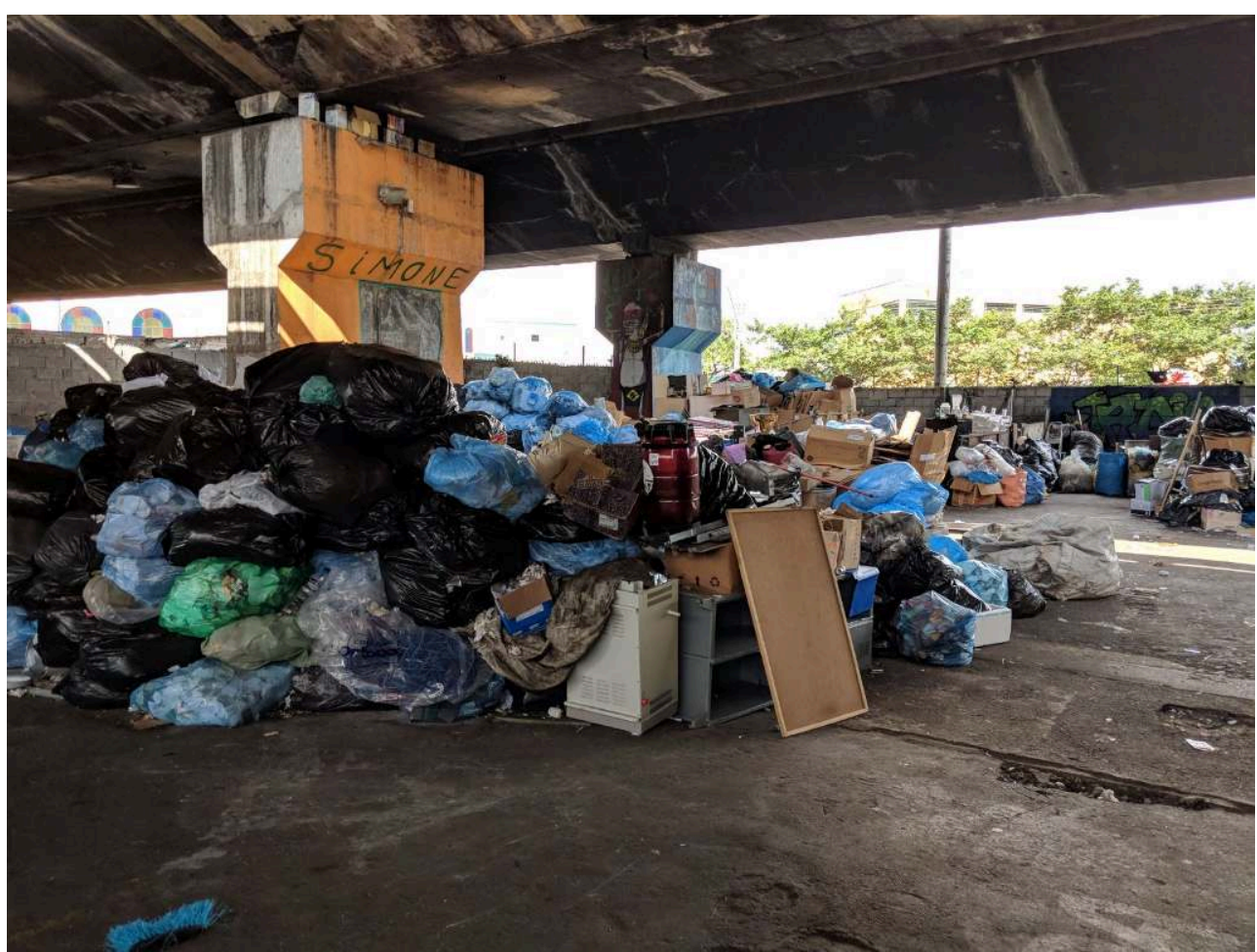

Photo by Alex Flynn 

as a meeting room, a bathroom, and finally the Dulcinéia workshop itself. Inside this cramped space is a waist-height trestle table and a large graffiti-style mural, the result of a previous collaboration. Shelves box in the space, on which the collective stores its stencils, tools, paper, stamps and all the other paraphernalia accumulated in creating a catalogue of 140 titles over a twelve years period. There is so little space in fact, that it is noticeable how the collective cleans up after each and every activity, placing every single item back into its unique place: the bradawls (agulhões), paper clips, box cutters (estiletes), metal rulers, paints, pots, brushes, etc. This is necessary not just to keep things organised, but also because Dulcinéia regularly uses this space for workshops, inviting members of the public, artists, university students and professors and other cartonera practitioners to co-create books here. In April 2018, for example, we found ourselves crammed into the space when Dulcinéia invited the Argentine publisher Biblioteca Popular Ambulante to work with them in order to create a co-edition destined for an exhibition in the North East of Brazil.

Both in the workshop and in the recycling coop itself, it is striking how the aesthetic of what Dulcinéia publishes is inspired by the space in which they are based. All around the Glicério coop are hand spray-painted stencils, the industrial, machined stencils of the cardboard itself, and the colourful labels that identify equipment as belonging to the Glicério recycling cooperative. These motifs echo throughout Dulcinéia's books and when Lúcia, Andréia, Maria and Eminéia are cutting cardboard for book covers, they take care to select certain pieces to make sure that the industrial stencils are visible on the book covers they create. This way, Lúcia explained, 'you know that the cardboard is reused and not somehow fake,' that is, a representation, a mock-up of a very particular aesthetic that comes directly from the street.

A wall adjacent to the Glicério recycling cooperative and the cover of a book produced by Dulcinéia Catadora
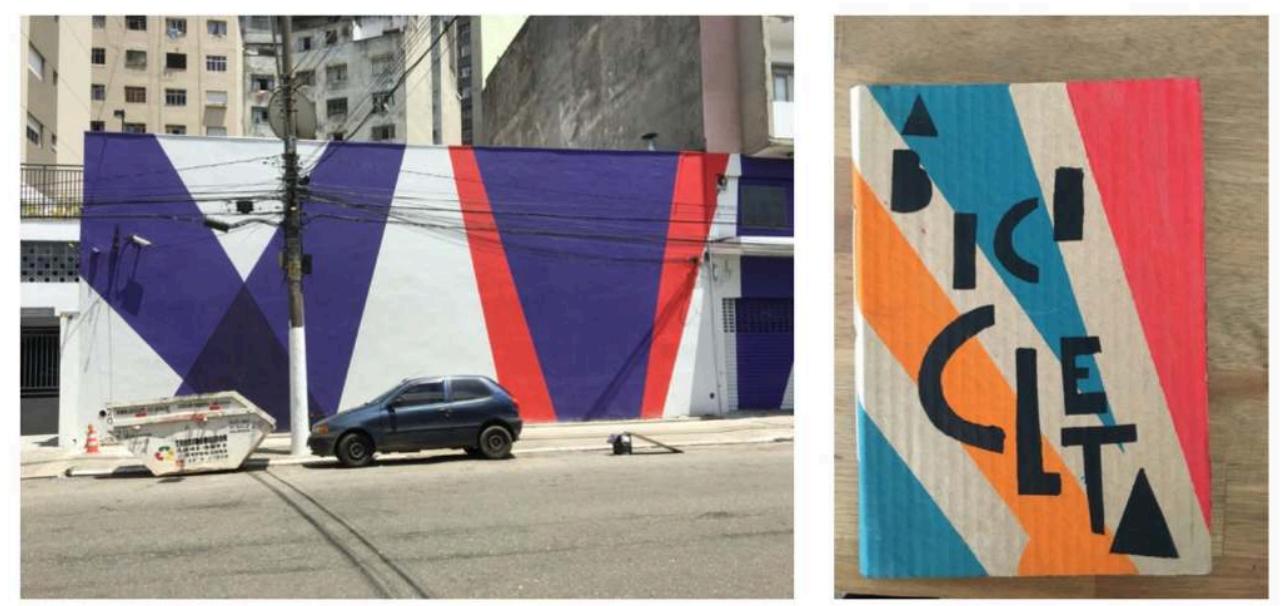

Photos by Alex Flynn

Dulcinéia's environment is interweaved through every stage of the production of their books, from the selection of the materials they use to bind their books to the designs and aesthetic forms that integrate the composition of the covers. These social forms of the space, including the very model of labour and recompense that the recycling cooperative operates, are integrated into Dulcinéia's practice, directly informing the 
aesthetic forms with which Dulcinéia work. What is interesting about Dulcinéia however, and indeed cartonera more widely, is how this indivisibility operates in both senses, a specific 'double-fold', that works across these forms and in both directions. Dulcinéia's aesthetic forms, informed by a specific context, extend beyond the Glicério coop and into other spaces, many times creating and shaping social forms. One such community in which the collective has worked is the occupied Hotel Cambridge project on which we have written elsewhere (Flynn 2018a, 2018b; Bell 2017b) and here we would like to describe in more detail just how the aesthetic informs the social, with an example of Dulcinéia Catadora's work in the Morro da Providência community in Rio de Janeiro.

\section{Dulcinéia Catadora: Além (beyond)}

11 On 1 March 2013 a new museum was being inaugurated in the centre of Rio de Janeiro's old town. The Museu de Arte do Rio, popularly known as MAR, is one of the centre pieces of a gigantic project of urban regeneration, an ongoing project that seeks to transform the city's dilapidated port zone into a shiny new commercial, cultural and residential space. In front of a striking architectural design that unites a nineteenth century palace, an old police facility and the former central bus station, the queue to enter was huge. At the welcome ceremony, João Roberto Marinho, of the Marinho foundation with assets of at $\$ 30$ billion, and the private stakeholder in the museum, smiled and made a play on the name MAR: 'I invite everyone to come play and dive into this sea'. But of course, not everyone was welcome: all the tensions inherent in the construction of a project that had been accused of gentrification right from the start were on display: security was tight, and visitors were aware of the proximity of the nearby favelas, including Rio's oldest, the Morro da Providência.

For the opening night, there were four exhibitions. One in particular, $O$ Abrigo $e$ Terreno (Shelter and Land), directly addressed questions of inequality focusing on the 'forces that come together and conflict in the urban, social and cultural transformations of the public and private space'. ${ }^{2}$ The show included many of the most significant artists in Brazil: Hélio Oiticica, Cildo Meireles, Cláudia Andujar, and in amongst this prestigious list, Dulcinéia Catadora. The collective had been invited by curators Paulo Herkenhoff and Clarissa Diniz to develop an artistic collaboration with the neighbouring Morro da Providência, creating a link between the museum and the surrounding marginalised communities As such, the project was entirely in line with the theme of the exhibition. Nevertheless, some, including Rio's mayor, Eduardo Paes, were of the opinion that Dulcinéia's inclusion was incongruous and politically, potentially disastrous. Paes even argued to have Dulcinéia removed from the exhibition but the curators stood firm.

13 To prepare for the exhibition, Dulcinéia conducted a yearlong series of workshops in the Morro da Providência, producing four texts, collectively written with residents, on the housing problems they faced and the risk of violence in their homes. On the eve of the 2014 FIFA World Cup, Dulcinéia's intervention brought about heightened attention to conditions in the favela, making plain how the house clearances for this mega-event and the imminent 2016 Rio de Janeiro Olympic Games were affecting the residents, materially, socially and psychologically. The four texts became integral to the opening night exhibition, with over 1,100 copies, painstakingly stitched, stapled, folded, glued and painted in the workshops, on display, and for distribution to visitors. In this way, 
cartonera practice created a temporary point of connection between the favela and Rio's most prestigious new cultural space, between the words and worlds of the Morro's residents, and the cultural and political elite of Brazil. Seeing, as James Elkins observes, is metamorphosis, not mechanism (1996: 12), and once these opening night visitors cast their eyes on the striking installation of hundreds of hand-painted cartonera books, in the symbolically resonant form of a wall, something small was put in motion: the feel of the rough texture of cardboard recovered from the street, the bold gouache colours that resignified an everyday disposable material, the neat stitching through irregular perforations that left no doubt that the books were handmade, unique, and came from somewhere very distant to a space like MAR.

Detail from the exhibition 0 abrigo e o terreno, Dulcinéia Catadora's installation to the right-hand side

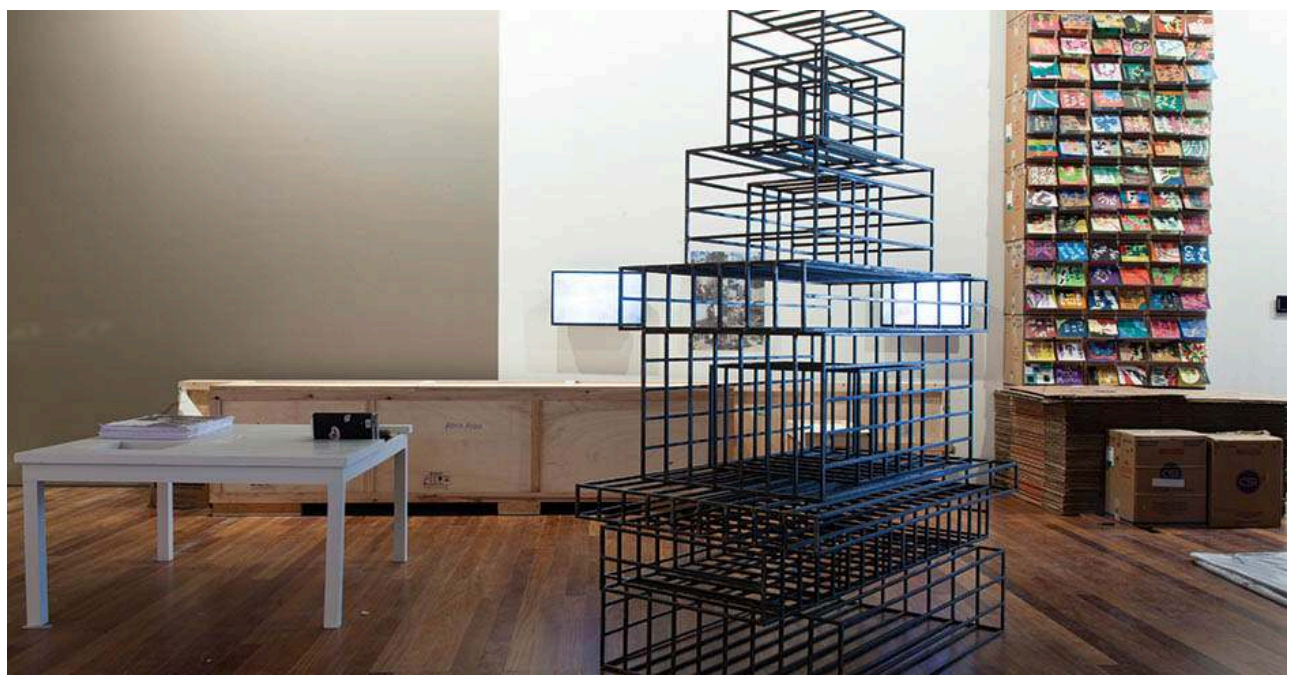

Photo by Lúcia Rosa

Outside the museum, there were several queues. One was for the grandees and their entourage. Another was for the general public. At the third, the queue for artists participating in the exhibition, there was a source of confusion. Andréia, one of Dulcinéia's members, had travelled from the Glicério recycling cooperative in São Paulo to attend. Later she told us: 'They see us as drug addicts, as street-sleepers. They see us, but they pretend not to see us, we are invisible to them.'. There was confusion with security and she was removed: barred from her own work, her own project, her own artistic labour. Just in time, Lúcia arrived, and they joined forces. Together, determined to enter, they embodied cartonera: a practice based on intervening, perforating, challenging and reconfiguring the deeply entrenched social stigmas that characterise the contexts in which they work. At the artists' entrance they demanded to be admitted and finally they were allowed to enter.

The exhibition, a form that is common to cartonera practice, became a type of battleground in which Dulcinéia's aesthetic intentionality managed to subvert sedimented social forms of exclusion. First, the initial refusal to allow Andréia to enter the exhibition reveals how being a member of Dulcinéia Catadora undermined museum security's decision to bar a catador, a waste-picker, from entering the space. Second, in the exhibition itself, MAR's opening night public was confronted with an unexpected and, for some people, unwelcome, reminder of the Morro da Providência's proximity, and the accompanying poetic and artistic agency of the people who lived within it. 
Threatened with eviction by the very scheme of urban 'revitalization' of which MAR was a key component, Dulcinéia's intervention opened a possibility for the Morro's residents to create their own architectural intervention in the space, a towering wall of cartonera books that was continually constituted and reconstituted as the museum's public took a copy home, while the museum's staff replenished the installation from the 1,100 editions created in community workshops. The very content of the text De Lá pra Cá, de Cá pra Lá (From there to here, from here to there) spoke powerfully of residents' desires to know and transit the spaces of the city, and how they connected this concept of circulation with group dialogues on rights and citizenship.

\section{Four Forms: Exhibitions, Workshops, Co-editions, Encontros}

The double-fold of the indivisibility of social and aesthetic forms convinced us that we had to work closely with this expanded idea of form. We began to analyse in what forms cartonera took shape and how we might think about working within these parameters. From ethnography with Dulcinéia Catadora but also from the data of our wider project, which spans Mexico and Brazil, working with cartonera publishers in Guadalajara and Cuernavaca, and Minas Gerais respectively, our ethnography points toward four consistent forms through which cartonera publishers operate: exhibitions, workshops, co-editions and encontros (gatherings).

The exhibition at MAR was just one of many in which cartonera practitioners participated or have initiated. Dulcinéia itself came about as a result of the 2006 São Paulo Biennale 'Como viver junto' (How to live together) and has participated in exhibitions at MAC Niteroi as well as the SESC Pompéia Cultural Centre among others. Catapoesia, a cartonera publisher based in rural Minas Gerais, has created eight exhibitions in spaces such as libraries, community museums and even a local bar. $L a$ Cartonera, based in Cuernavaca, Mexico, organised an elaborate retrospective exhibition in the Galería La Barranca, within the Chapultepec park in March 2018, celebrating their ten-year anniversary as a collective, and have participated in exhibitions in Chile and France.

18 Cartonera exhibitions tend to be embedded in processuality and it is important to foreground that Dulcinéia's installation at MAR was made possible by a year-long series of face-to-face sessions with residents of the Morro da Providência: it is impossible to overlook how workshops are a key organizational form for cartonera publishers. The affordances of workshops are multiple, employed as they are as modes of production and dissemination, as means of fulfilling pedagogical principles, of widening access to literature, and of working with communities and individuals. La Cartonera, for example, hold a weekly workshop session in which covers are co-created and new aesthetic forms are experimented with, while almost all of Catapoesia's output is produced collectively in community workshop contexts. La Rueda, based in Guadalajara, has produced dozens of titles since 2009, and many of their books are made by hand in workshop contexts.

This kind of co-production is typical of the collective spirit that unites this otherwise loose publishing network and there is a marked emphasis on collaboration. One of the foundational texts that first sparked collaboration across diverse collectives was the 
2008 co-edition of Mario Santiago Papasquiaro's Respiración del laberinto, a collection that was conceived at a cartonera encontro in Wisconsin. More recently Dulcinéia have published co-editions of $O$ Gato Peludo in Spanish and English with the Peruvian collective Sarita Cartonera and Underwood portátil, by Mário Bellatin, with La Cartonera and Vento Norte Cartonero. The occasion for these kinds of collaborative opportunities is usually at an encontro, in all the extended Portuguese senses of the word (meeting, gathering, convergence, conference). An encontro is a method of networking, while also disseminating and celebrating work, regularly used by cartoneras. Most prominent is the yearly encontro cartonero in Chile, but there are many others, like the noches cartoneras, 'cartonera nights' (more recently renamed francachela cartonera, 'cartonera revelry') that accompany Guadalajara’s annual International Book Fair (FIL).

\section{Theoretical Points of Inspiration: Context} cartonera publishing, emerged as we became better acquainted with our project partners. We became convinced that our project's methodological framework should be developed in response to our experiences of cartonera publishing's very particular double-fold, working with a two-way process that moves across aesthetic and social forms. Of particular interest was how cartonera practices can intervene to create spaces for transformation, and how in many cases this process is premised upon a disruption or dissonance, challenging consensual orders and posing alternatives. Jacques Rancière's (2009) work on the politics of aesthetics is therefore interesting for us for a number of reasons. First, Rancière argues that aesthetics and politics cannot be separated, that aesthetics is the means through which the political is constituted and operates; second, politics, for Rancière, is not a party political system or a more traditional reading of power and hierarchy, but rather 'the configuration of a specific space, the framing of a particular sphere of experience, of objects posited as common and as pertaining to a common decision, of subjects recognized as capable of designating these objects and putting forward arguments about them' (Rancière 2009: 24). As Brian Larkin in his reading of Rancière has suggested, 'politics takes place when those who occupy fixed positions outside a certain order decide to intervene within that order. It is the apportioning that determines who can participate in a system' (Larkin 2018: 187); as Rancière states: 'this distribution and redistribution of places and identities, this reapportioning of spaces and times, of the visible and invisible, and of noise and speech is what I call the distribution of the sensible' (2009: 24-25). Artistic practices, in Rancière's account, are thus not privileged means of understanding 'reality', but "'ways of doing and making" that intervene in the general distribution of ways of doing and making as well as in the relationships they maintain to modes of being and forms of visibility' (Rancière 2004: 8). All art, in that sense, is political - and, conversely, 'there is [...] an "aesthetics" at the core of politics' - because both are built on sensory perception, on 'what is seen and what can be said about it, around who has the ability to see and the talent to speak' (Rancière 2004: 8). Both are capable of producing equality and inequality, inclusion and exclusion.

21 
of medium being editorial, the publishing of books. I thought a lot about Joseph Beuys' concept of social sculpture in relation to Eloísa Cartonera'.

However, Eloísa's output clearly proposes certain challenges to art historical readings: its works have a defined price; they are co-authored in many senses; they are displayed many times in spaces beyond the typical environs of contemporary art circuits; and as a publisher, the gesture towards social intervention occurs over a period of decades. Thinking through this interstitial location and developing a previous line of thought on art practice at a series of intersecting axes (Flynn 2018a) we have worked with Néstor García Canclini's (2014) concept of post-autonomous art, a theory that owes much to Rancière's thought. García Canclini argues for a type of contemporary artistic practice that sits within a particular arrangement of porous frontiers that characterizes contemporary artistic production:

With this word I refer to the process of last decades in which displacements from artistic practices based on objects to practices based on contexts have increased, up to managing inserting the works in mass media, urban spaces, digital networks and forms of social participation, where the aesthetic difference seems to disappear. (García Canclini 2014: 17).

For García Canclini, what was once theorised as a hermetic 'system,' or an art world with definable boundaries and conventions, can no longer be contained within these terms. Art is no longer a singular field with a limited range of actors, such as the idealized artist, the gallerist, or the curator, nor is it practised within a series of definable locations, such as the 'white cube' gallery, the museum, or the private space of the collectors. Post-autonomy, the condition that characterises work that exists in interstitial spaces, is an evitable consequence to a contemporary history of art that García Canclini characterises as 'a paradoxical combination of behaviours to strengthen the independence of the art field [while] stubbornly trying to destroy the borders that demarcate it' García Canclini 2014: 15). Processuality here is important: post-autonomy is premised on a movement away from artistic practices based on objects to practices based on contexts. Such work is intensely processual, as can be seen from Dulcinéia's intervention in the Morro da Providência for example, and for García Canclini, processuality is ultimately how he imagines Rancière's conviction in art's potential to constitute new collective worlds to be realised.

Given the intersections between Rancière's and García Canclini's theories, it is unsurprising that both call for the development of new methodological approaches capable of overcoming the limitations of traditional methodologies from both the social sciences and also literary and art historical disciplines, even if their suggestions are somewhat speculative (Papastergiadis 2014). Tijen (2015) highlights how García Canclini's work on art from an anthropological perspective is refreshing in that it chooses to focus specifically on form as opposed to the more common paths of price and market that continue to fascinate anthropologists and sociologists alike. And García Canclini himself points toward how the answers to these questions may be located in working more closely with artists themselves: 'What roles do artists such as Antoni Muntadas, León Ferrari, and Carlos Amorales play when they reconsider these same ties of interdependence in their works and stagings?' (García Canclini 2014: xvi). This last point is important to us, as we have become convinced that while methods need to be developed in dialogue with theoretical advances and debates, they also need to be thought through collaboratively alongside the people with whom we work, bearing in mind their specific, situated and reflexive artistic practices. 


\section{Theoretical Points of Inspiration: Moving Forward}

Caroline Levine's pioneering formalist propositions helped us to approach our work on methodology with greater purpose and clarity. In Forms: Whole, Rhythm, Hierarchy, Network (2015), Levine argues:

An attention to both aesthetic and social forms returns us to the very heterogeneity at the heart of form's conceptual history. [...] All of the historical uses of the term, despite their richness and variety, do share a common definition: "form" always indicates an arrangement of elements-an ordering, patterning, or shaping. Here, then, is where my own argument begins: with a definition of form that is much broader than its ordinary usage in literary studies. Form, for our purposes, will mean all shapes and configurations, all ordering principles, all patterns of repetition and difference. (Levine 2015: 3; italics by the author)

Levine's reinvigoration of formalism, based on a refusal to distinguish between literary and social form, allows us to construct an analysis of cartonera that acknowledges the double-fold that this practice enacts between different configurations of form. This repurposed approach furnishes a means of moving between textual analysis and ethnography, recognizing the potentiality of the broader etymology of the word 'form' (or 'forma') in Spanish and Portuguese, where it denotes not only shape, form or figure but also way or mode. Within this mode of reading, forms of action - ways of doing things, of changing things, of shaping experience - necessarily intersect with aesthetic forms - ways of shaping objects, words and experiences. Turning to cartonera texts as 'theorization[s] of the social' (Levine 2015: 134) enable us to research not on, but in processual dialogue with cartonera publishers as creative, reflexive, social actors; to overcome the obstacles within and between academic disciplines that lead us to focus on different issues in relative isolation (Chaddha and Wilson 2011); and thus engage with social practice, aesthetic form and collective imaginaries.

In order to develop methods that were true to this notion of artistic practices as 'theorizations of the social,' however, we needed to move away from a tendency, present in Levine's work, to privilege the literary critic as a reader with VIP access to understanding forms - the ways they work, the possibilities they afford and their transformative potential. In order to do so, it was necessary to engage seriously with the post-critical turn that in recent years demands that researchers question a mode of reading and a dominant paradigm in the field of literary and cultural studies - critique - that has tended to 'render the thoughts and actions of ordinary social actors as insufficiently self-aware or critical' (Anker and Felski 2017: 14). As Anker and Felski point out, the possibility of separating between ordinary social actors and privileged critics has been fuelled by prevailing antagonistic and combative trends in the humanities, particularly since poststructuralism, which in spite of its radically democratic underpinnings has in fact fostered a 'spirit of marginality' and thus 'kept serious thought sequestered in the ivory tower' (ibid.: 19).

Levine (2015) arguably falls into the same trap when she locates formalism in academic - and specifically literary critical - approaches to form:

'One has to agree to read for shapes and patterns, of course, and this is itself a conventional approach. But as Frances Ferguson argues, once we recognize the organizing principles of different literary forms - such as syntax, free indirect speech, and the sonnet - they are themselves no longer matters of interpretative activity or debate.' (Levine 2015: 13) 
ine thus anchors formalism in acts of reading rather than artistic acts or practices themselves, rooted in conventional literary critical approaches, missing out on the particularity of how these 'shapes and patterns' are locally and specifically contextualised and contingent. These in turn become normalizing perhaps recalling the work of Ruth Benedict's Patterns of Culture (2005), or even structuralist approaches, the universalizing notion that human societies and communities worldwide were organized by shared structures which has, as Levine (2015) acknowledges, undergone fierce criticism for 'assuming that these patterns were natural and therefore inexorable' (Levine 2015: 5).

er approach leaves room for questions, which themselves pave the way for further methodological experimentation: how can generalizing formalist methodologies be reconciled with ethnographies located in concrete, ever-unfolding experience? What happens when aesthetics, which has often served as a tool for theoretical development, is considered as a research method in itself? To what extent can academics become involved in more creative, collaborative, participative, immersive activities, like cocurating exhibitions and media experiments (Lash 2007: 75), while retaining their credibility as rigorous researchers?

\section{A Trans-formal Methodological Framework}

31 The 'trans-formal' methodological framework which we have developed in response to our experiences of cartonera publishing is premised on the double-fold process that moves across aesthetic and social forms. The term 'trans-formal' is used to define a methodology able to operate across different aesthetic, literary, discursive, social, political, and material forms, across human and other-than-human forms, and across different kinds of form (shapes and actions, spatial configurations and temporal practices). On the one hand, this means approaching the social forms at play in cartonera practices through methods deriving from the aesthetic forms of cartonera practices - a departure from Levine but following the logic of her radical formalist proposition. On the other hand, it means reading the texts - post-critically - as interventions in, and creative reflections on, these social forms; in other words, we see the texts as generators of their own critical thought and theory.

The central pillar of our methodological framework is the notion of emulation. Emulation most commonly refers to efforts to match or surpass, typically by imitation: artists, artisans and architects for example may seek to emulate natural forms in their work, for example by invoking the Golden Ratio, a universal constant that has long been known and used. But emulation also has a more contemporary meaning. The second entry for emulation in the Oxford English Dictionary defines it as 'reproduc[ing] the function or action of (a different computer, software system, etc.)' ${ }^{3}$ which is the basis for Techopedia's expanded definition and contextualisation:

Emulation is the process of imitating a hardware/software program/platform on another program or platform. This makes it possible to run programs on systems not designed for them. Emulators, as the name implies, emulate the functions of one system on another. Thus, the second system behaves like the original system, attempting to exactly reproduce the external behaviors of the first system. ${ }^{4}$

Although we do not subscribe to the notion of hermetically separate, entirely different systems, the notion of a research team enacting an emulation through a commitment 
to processuality was interesting for us and we explored the possibilities of working in this manner. Through our fieldwork, literary analysis and conversations with project partners, we identified four forms through which cartonera practitioners operate but also make possible: exhibitions, workshops, co-editions and encontros. We then decided to emulate these forms in our own fieldwork, with three central justifications: first, that cartonera was a highly reflexive process and these were their already existing forms of investigation and research; second, that such an approach would directly contribute to the cartonera community, creating better conditions of horizontality throughout the project lifespan and beyond; third, and crucially, that in assuming these forms that traversed the social and the aesthetic, we would not only be researching, but also producing knowledge that originated in a space closer to cartonera's positionality with regards to the distribution of the sensible.

In practice, this involved designing participatory, creative methods, which - crucially - were not laid out from the start, but rather emerged from months of work on the texts and dialogue with our partners in Mexico and Brazil. What emerged was a constellation of practice-based methods, co-productions with our cartonera project partners, which emulated the very exhibitions, workshops, co-editions and encontros that we had first come upon and in which we had enjoyed participating. What was particularly significant for us however, was conceptualizing method not only as assemblage, but also as an open-ended set of processes, and this has been crucial to developing these more horizontal, interdisciplinary approaches.

\section{Exhibitions}

As we have discussed, cartonera publishers commonly exhibit their work, and we decided to create an exhibition of cartonera work in São Paulo in close discussion with our cartonera project partners. The exhibition, which took place in the Casa do Povo cultural space from 1 November 2018 to 9 February 2019, was the largest exhibition of cartonera work to date, featuring over 350 books from thirty-five different cartonera collectives. Amongst works from Brazil, Mexico, Paraguay, Argentina, Chile, Peru, Bolivia, Colombia, Germany and France, our four project partners' books were specifically foregrounded, along with works from the publishers Yiyi Jambo and Eloísa Cartonera. The exhibition also included four short films, documenting different methods of constructing cartonera books and a longer documentary by the filmmaker Isadora Brant. The production process for this film expanded our ethnography in unexpected ways: we travelled to Buenos Aires and Rio de Janeiro as well as across São Paulo to gather materials and as a consequence interviewed actors which otherwise we might not have come across. The exhibition was co-curated by Alex Flynn and Beatriz Lemos and the curatorial process occurring between an anthropologist and a full-time curator provoked many interesting points of similarity, as well as points of disjuncture. As discussed elsewhere (Flynn 2019), curating an exhibition offered an interesting parallel to traditional ethnography. 
The staircase module, itself an emulation of the Casa do Povo's entrance staircase with area for seating built into the display.

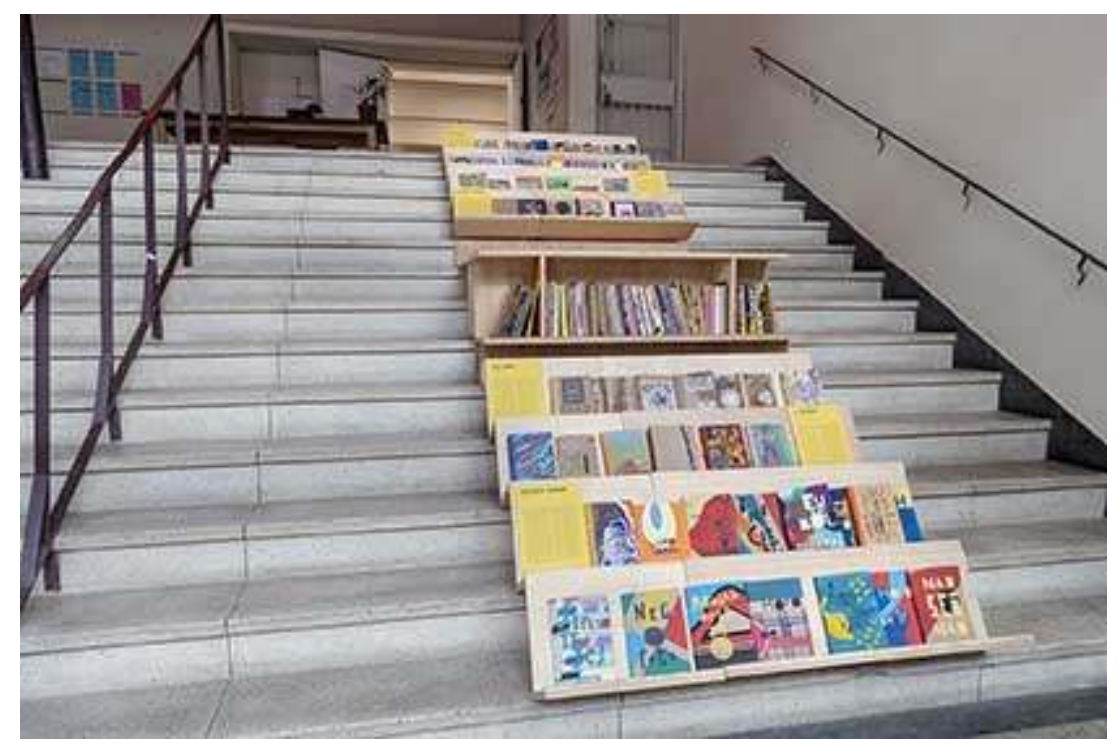

Photo by Alex Flynn

First, the presential, processual nature of work that invites one actor to accompany the other in their day-to-day practice lead to the development of affective and embodied relations. Second, the realisation of a field of work in which there are multiple actors, each with unique spheres of practice, to whom we had diverse responsibilities, required us to mediate diverse positionalities. And third, there was a strong emphasis on synthesizing a conceptual narrative from within (although not necessarily about) these positionalities and multiple actors, the construction of a body of work, and the inherent reflection that this suggests. We began with a goal to better understand how cardboard publishers sought to transition a literary work into a visual sphere and the processual nature of constructing a complex exhibition allowed us to gain a privileged insight into how the post-autonomous literature of Ludmer's (2007) conception - a literature that traverses borders being at once outside and inside - enters into dialogue with aesthetics, exhibition design, and importantly for our work, politicized public space. One of the key driving principles of the exhibition design was that all the books on display should be accessible, that is, not protected by -glass from the visitors' hands and touch. As a project team we wanted visitors to be able to engage phenomenologically with the books and the exhibition catalogue echoed this idea. Printing two booklets, one in Spanish, the other in Portuguese, recognising cartonera's pan-Latin-American intentionality, we created a workstation with cardboard from the Glicério recycling cooperative, paints, paintbrushes, boxcutters etc - in short, a typical cartonera workshop - so that visitors to the exhibition, in taking home the catalogue could create their own cartonera book, supervised by the public programme team. Over the duration of the exhibition, over 300 catalogues were created in this manner allowing us to work alongside people encountering cartonera for the first time, both literally and affectively. 


\section{Workshops}

37 A key part of the exhibition design was to think of the books as points of potential interaction, thus making possible a space of relations and exchanges. While this design counted on a certain didactic content, such as the tutorial videos and the documentary film explaining where cartonera had come from, it was our intention that the space should essentially function to welcome visitors to come in and sit down, pick up a book, and come to their own understanding of the cartonera phenomenon. We also thought of the books as enacting a type of proto-cartonera library, as we were creating a concentration of cartonera literature never before seen in a public space. It seemed to us that just as a university library would be a starting point for many research processes, a cartonera library could function in the same way, although importantly, with different basic rules of access, copyright and interaction. As such the workshops articulated by the exhibition's public programme team, directed by Graziela Kunsch, were an integral part of what we hoped the exhibition could achieve, and in doing so, perhaps expand on what an ethnographic process might not encompass.

The public programme organised various activities, three of which we will highlight here. First, Dulcinéia Catadora led three workshops in the exhibition space exploring immigrant women's perspectives of São Paulo. The participating group, compromising representatives of three different feminist and LBT (Lesbian Bisexual Transgender) collectives, worked together to create a series of texts that spoke to their experience of living in São Paulo. Over the three sessions, the participants created a cartonera book of these short texts, which through a complex series of folds, became an A2 placard of protest to be used in a march following the third session. Second, in the process of working throughout the exhibition, two members of the public programme team created their own cartonera publisher, Sin Fronteira Cartonera, echoing how Dulcinéia Catadora came into being during Eloísa's workshops at the 2006 São Paulo Biennale. 
The workshop ly mũn ku mãk pax investigated the silencing of indigenous languages and histories.

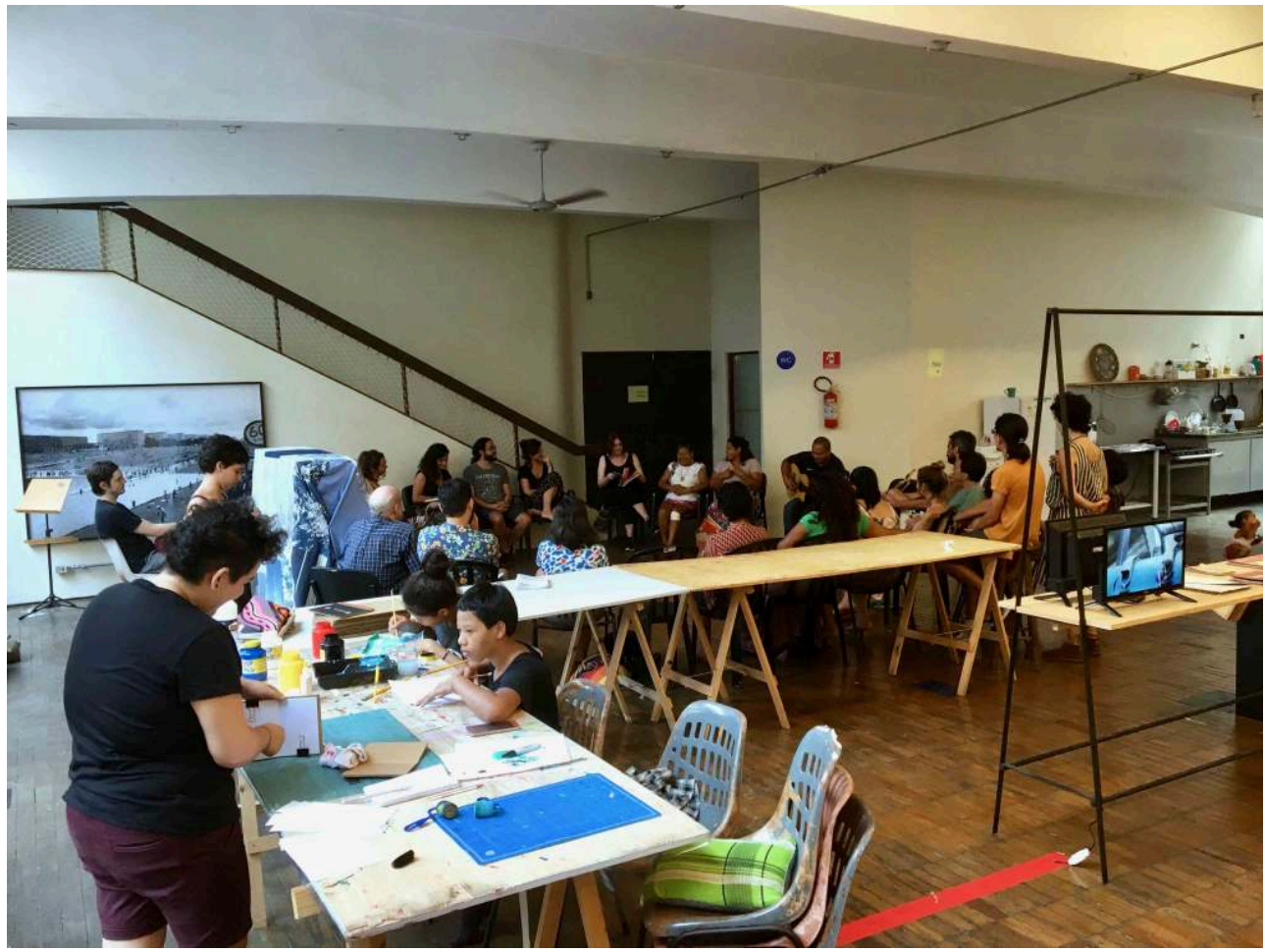

Photo by Alex Flynn

Over a series of sessions, they produced six books, including Dialogos, reflexiones $y$ desafios en Colombia: Hacia un feminismo popular (Dialogues, reflections and challenges in Colombia: Towards a popular feminism), a text organised by the Colombian feminist collective Red de Mujeres de La Sabana. And finally, to close the exhibition, we organised the event Iy mũn ku mãk pax, an event designed to bring into focus languages spoken in Brazil beyond those of the colonizers, Portuguese and Spanish. This event took place over two days and, inspired by the bi-lingual texts of Yiyi Jambo in the exhibition that create a deft interplay between Portunhol Selvagem, Portuguese and Guarani, the event sought to work with themes of how colonial structures have systemically silenced indigenous languages and literature. Juanito Cusicanki and Beatriz Morales of Aymara and Quechua ethnicity respectively, were invited to present their indigenous alphabets, based on their oral knowledge. In the second workshop, representatives of Guarani, Pankararu and Baniwa peoples spoke about their experiences of state kidnapping and the following imposition of Portuguese on their communities. Contextualised by these moving accounts, the title of the event came to hold a particular significance: from the shamanic chant maxakali / tikmũ'ũn, Iy mũn ku mãk pax meaningss 'my beautiful voice'.

\section{Co-editions}

Workshops, as described above, many times generate cartonera books, either in terms of their format (the binding process), their artwork (the painted covers), or their content (the text themselves). Unsurprisingly, given the collective spirit that unites this otherwise loose publishing network, collaborative publications are a hallmark of cartonera literature. We decided that to take cartonera seriously as a form of knowledge 
production, as a research project, we should also publish in cartonera form. This was again a process of emulation premised on the double-fold notion of form: first, publishing in cartonera form meant engaging in the social form of co-creation, which meant revealing all the accumulated knowledge built into an academic research process to our project partners, including executive summaries, budgets, research questions and stated outputs; second, engaging with the aesthetic of cartonera, understanding how many pages could be bound by different types of stitching, working with our texts beyond the two dimensional interface of a word processing programme, and understanding that what we wrote would reach a radically different audience from an academic output located behind a paywall, altered what we wrote and how, giving us a deep insight into the writing and editing processes of cartonera production.

41 The project worked with two principal co-editions. First, we co-published a text entitled Cartoneras in translation, with our four principal project partners, Catapoesia, Dulcinéia Catadora, La Cartonera and La Rueda. This text included contributions from each publisher, and an afterword, co-authored by the research team. Each text was translated from Spanish or Portuguese to English, and the colophon, afterward and contents page appears in three languages. Not only contributing to this text, but also accompanying its production revealed the highly specific nature of cartonera publication, and how a production method in Mexico could be entirely out of sync with the equivalent process in Brazil. The second text we have co-edited is an extension of a Dulcinéia model, entitled Vocabulario Vivido, an alternative dictionary built on subjective lived experiences rather than more typical normative definitions. While Lúcia Rosa used this model to explore the experiences of moradores (dwellers) living in the Hotel Cambrige Occupation in São Paulo, we have employed it as a means of engaging with key words from cartonera discourse from the standpoint of their diverse experiences rather than from a reductive and potentially colonial perspective. 
A text, an object of protest - Somos mulheres imigrantes
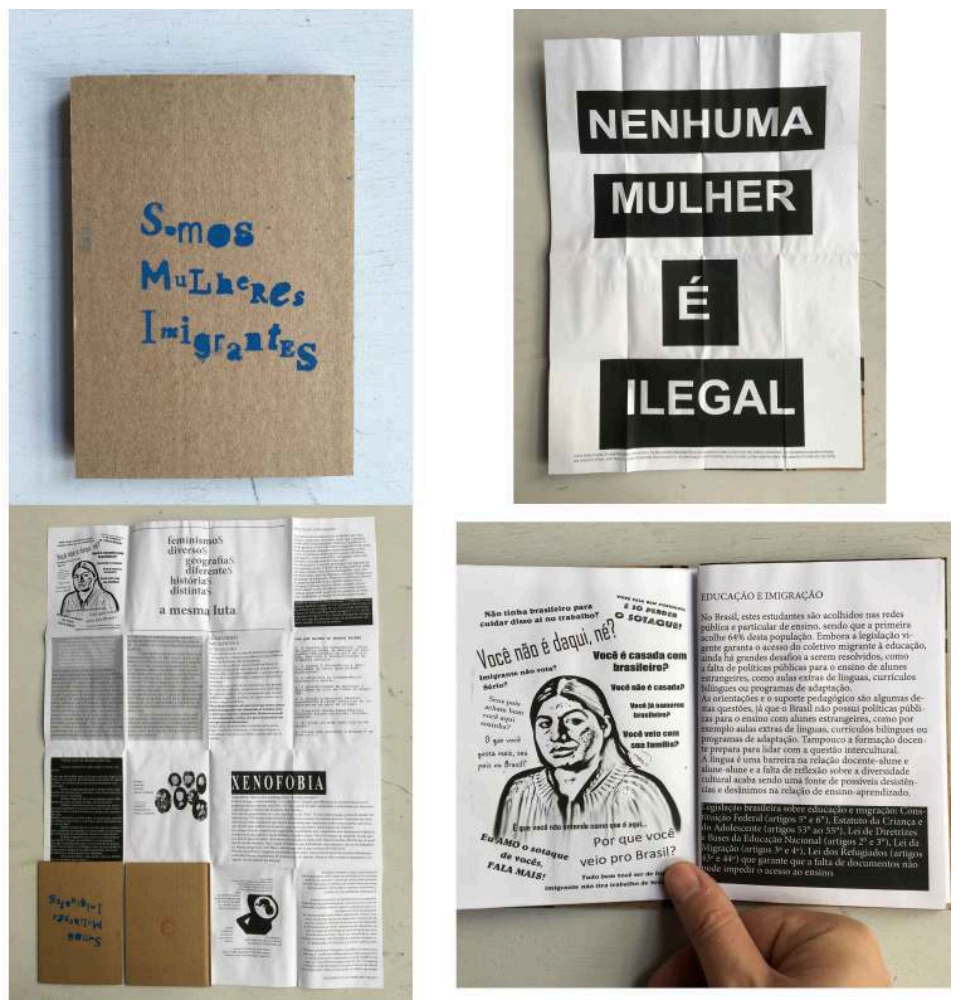

Photos by Alex Flynn

42 This Vocabulario cartonero (2019) is the result of a series of conversations with our project partners, and while it provides insight into the elements that connect and distinguish the collectives, obtaining this type of data was not our principal motivation. Rather, we suggest that Vocabulario Vivido is a form that has emerged organically constituting a reflexive means of research from within cartonera practice itself. In working with the notion of co-edition, we therefore seek to not just adopt and emulate a mode of publishing, but also highlight how in engaging with the forms of project partners, many times the best modes of research are already located within their everyday practice, or, as Lúcia Rosa dryly commented 'parece que o feitiço virou contra o feiticeiro' (it seems the spell has returned to act against he who cast it). 
Cartoneras em tradução: to the left, Catapoesia's edition, to the right, Dulcinéia Catadora's.

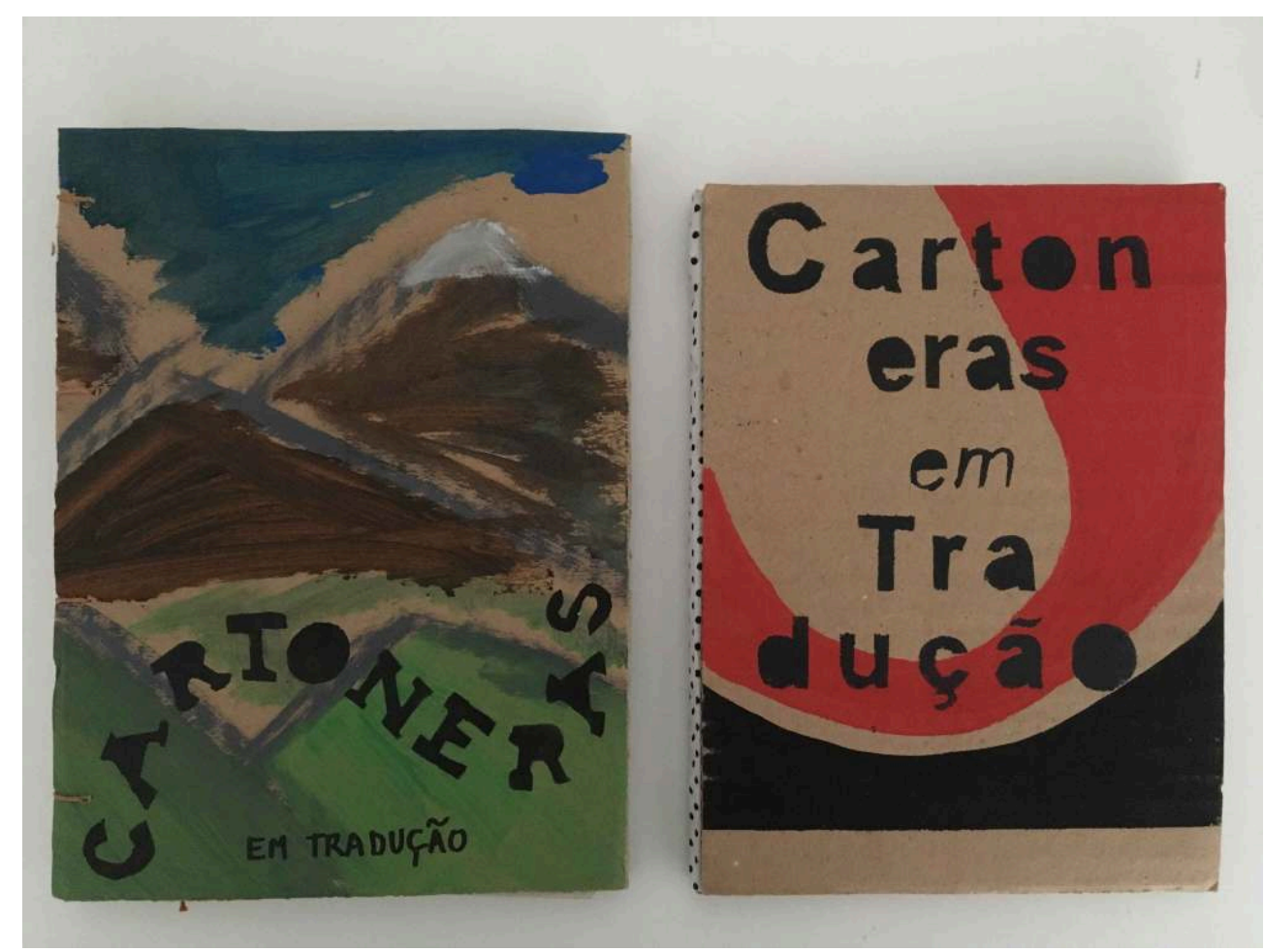

Photo by Alex Flynn

\section{Encontros}

Cartoneras em tradução was launched in the week following the opening of the exhibition at the Casa do Povo. It was timed to coincide with the first event to be held in the exhibition space, an encontro cartonero, a two-day event to which we invited cartonera practitioners from various cities across Mexico and Brazil as well as Buenos Aires, New York and London. As we discussed above, encontros are a method of networking, disseminating, and celebrating, regularly used by cartoneras across Latin America. This encontro was designed to fulfil a similar purpose and it echoed a smaller event we had organised in March 2018 in Cuernavaca. Both encontros sought to bring cartonera practitioners into face-to-face dialogue, a significant difficulty within cartonera networks due to the cost of travel in Latin America in relation to the minimum wage. ${ }^{5}$ The encontro was therefore an opportunity to fund practitioners and fortify existing networks, creating an opportunity for people to catch up, exchange and sell books, and make connections and discuss new projects. We organised a series of roundtable discussions in collaboration with our four project partners to stimulate conversation on cartonera. 


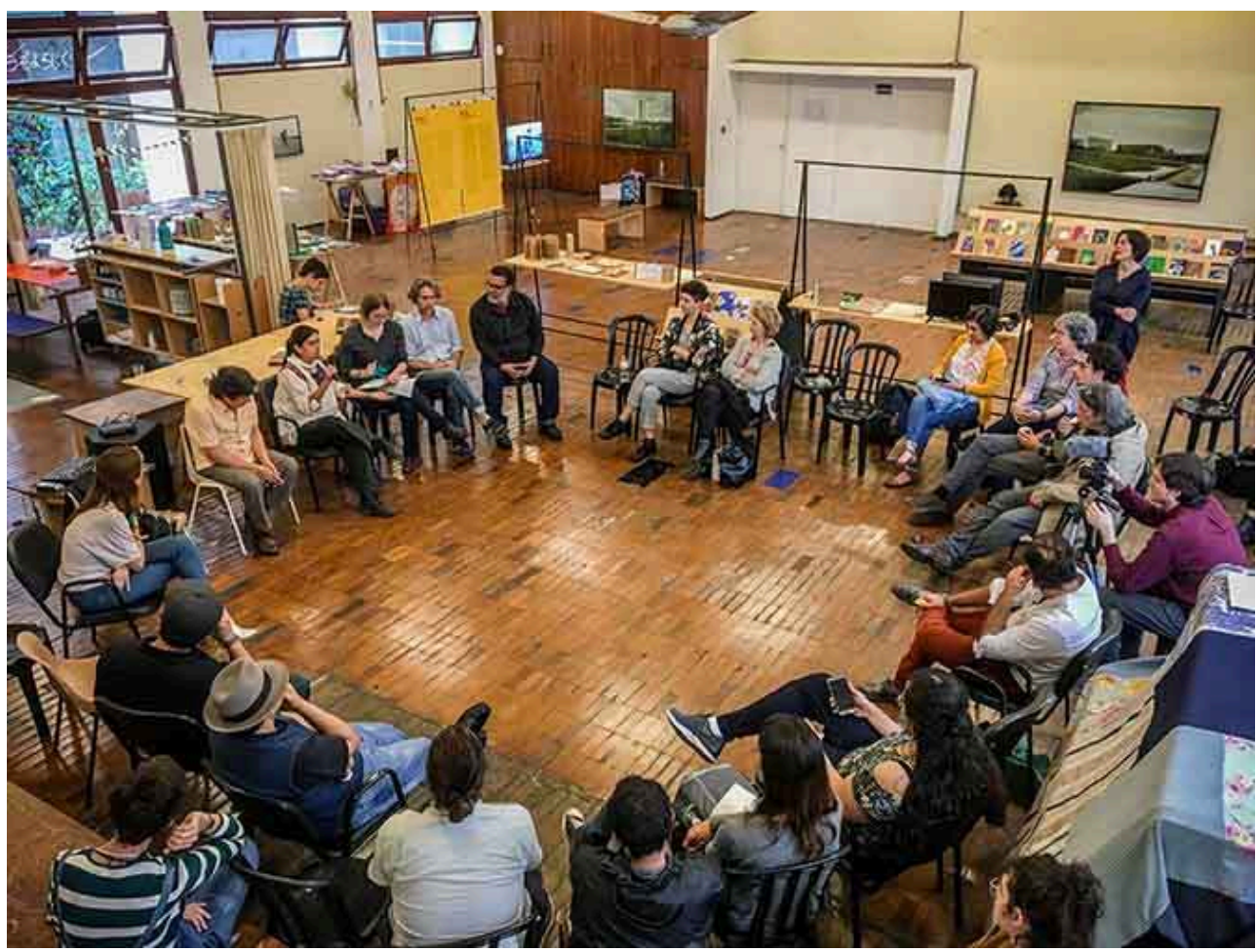

Photo by Alex Flynn how and why cartonera had managed to spread across the world, where people felt cartonera had come from and where it was going, and the tension between the cartonera book and the status of art object it might assume in an exhibition. As well as fuelling a number of productive discussions around the topics of cartonera aesthetics and politics, both the encontro in Cuernavaca and that of São Paulo generated a number of collaborations and co-editions: a collection of manifestos that resulted the discussions in Cuernavaca; and in São Paulo, a collection of political texts, entitled BR, responding directly to the 2018 victory of Jair Bolsonaro in Brazil's presidential elections. In organising these events, our intention was not to read any such texts produced critically, but as modes of critique in themselves, which both underline and problematize the form of the encontro as a mode of social and aesthetic action.

This forum was also an important opportunity for the wider cartonera community to question us as a research team and seek clarification on our motives for becoming involved with cartonera. At the beginning of the research project Pensaré cartonera, a publisher based in San Cristobal de las Casas in Mexico, had been forthright in their critique of our research, posting publicly in the largest cartonera forum of their experiences with our academia:

We decided to share our reflection so that it can serve, on the one hand, as a mirror and reflection on the relations between Academia and Cartoneras, which seem to be increasing. We must also be aware that in many cases - perhaps in this case these relations have consequences on concrete bodies, on broader social relations, and foster the hierarchical system of oppressions already in play. (Facebook 2018)

The encontro in São Paulo provided a valuable opportunity to invite a representative from Pensaré, amongst other cartonera publishers, to discuss these specific questions in 
a broader, public forum. This direct communication helped us as a project to reflect on the hierarchical relations that indeed, structure such interactions, and the structural limitations that acted upon our attempts at horizontality, as European, white researchers, with contracts at powerful British institutions of higher education. Perhaps more than anything else, the form of the encontro allowed us to better appreciate the complex inequalities and hierarchical knowledge production relations that are at play in the interface between cartonera publishing and a wider world.

\section{Conclusion}

47 As we outline above, social and aesthetic forms do not operate exclusively of one another, instead they are involved in a complex double fold, each arranging and ordering the other. The social forms of cartonera, including diverse models of labour and methods of production, are integrated into each publisher's practice, directly informing the aesthetic forms with which they work. Equally, each cartonera publisher's aesthetic forms, informed by a specific context, extend beyond their sites of production and into many other spaces, reordering and reconfiguring the broader social forms that characterise the communities in which they are based.

To design a methodology that recognises such interdependent oscillation, we started with an expanded notion of form and sought to identify the key forms through which cartonera operated. Anthropology has long worked comfortably with social forms, but this project makes plain that aesthetic forms are co-constitutive of the dominion in which anthropology has established itself, the social: thus, to ignore aesthetics' power to reorder is to overlook a key vector of sociality. This realization prompted us to engage with a process of emulation: in discussion with our project partners, we took on board the forms of cartonera and deployed them to structure our own research enquiry in order to work directly with cartonera's existing methods for research, make a direct contribution to the cartonera community, and crucially, not only research, but also produce, knowledge from a hybrid positionality that fundamentally redistributes places and identities within the order of researcher and researched. In this manner, we engaged with both the production and consumption of cartonera texts and objects, contextualising their potential effects and affective potential through the sociomaterial forms of cartonera practices in which they were embedded.

While working in this manner demonstrated our commitment to moving away from twentieth century model of ethnographic research, we accept that like Derrida's democracy $(1994,1997)$, horizontality is something we strive towards but must necessarily fail at, and therefore strive towards all the more. As researchers, we have been made constantly - and sometimes painfully - aware of the difficulties, if not impossibility, of achieving horizontality between our work as researchers working on funded projects supported by higher-education institutions and funding bodies in the Global North, and the work of social actors operating in complex contexts in the Global South, either lacking or refusing (on political grounds) institutional or state support. What our approach has given us however, is a practical pathway to carry out research that departs from Rancière's $(2004,2009)$ conviction in the centrality of aesthetics to politics. And perhaps beyond the concrete benefits of emulation and understanding another's enquiry in an affective, embodied sense, it is in working to distribute and 
redistribute places and identities through the unique configurative properties of an expanded notion of form, that our approach can offer a broader contribution.

\section{BIBLIOGRAPHY}

Books and articles

Anker, Elizabeth S. and Rita Felski. 2017. Critique and Postcritique. Durham and London: Duke University Press.

Bell, Lucy. 2017b. Recycling Materials, Recycling Lives: Cardboard Publishers in Latin America. In Literature and Sustainability: Concept, Text and Culture. A. Johns-Putra, J. Parham and L. Squire, eds. Pp. 84-106. Manchester: Manchester University Press.

Benedict, Ruth. [1934] 2005. Patterns of Culture. Boston: Mariner Books.

Bilbija, Ksenija and Paloma Celis-Carbajal, eds. 2009. Akademia Cartonera. Madison: Parallel Press.

Chaddha, Anmol, and William. J. Wilson. 2011. "Way Down in the Hole”: Systemic Urban Inequality and The Wire. Critical Inquiry 38(1): 164-188.

Derrida, Jacques. 1994 Spectres of Marx: The State of the Debt, the Work of Mourning and the New International, trans. Peggy Kamuf. New York and London: Routledge.

Derrida, Jacques. 1997. Politics of Friendship, trans. George Collins. London and New York: Verso.

Elkins, James 1996. The Object Stares Back: On the Nature of Seeing. New York: Simon and Schuster.

Epplin, Craig. 2009. Theory of the Workshop: César Aira and Eloísa Cartonera. In Akademia Cartonera. Ksenija Bilbija and Paloma Celis-Carbajal, eds. Pp. 53-72 Madison: Parallel Press.

Flynn, Alex. 2018a. Contemporary art in the Global South: Occupation // participation // knowledge. In An Anthropology of Contemporary Art: Practices, Markets, and Collectors. Thomas Fillitz and Paul van der Grijp, eds. Pp. 179-195. London et al.: Bloomsbury Academics.

Flynn, Alex. 2018b. Reconfigurando a cidade: arte e ocupação no Hotel Cambridge em São Paulo. Revista Plural 25(2): 20-45.

Flynn, Alex. 2019. On Anthropology, On Curation. In The Anthropologist as Curator. Roger Sansi, ed. Pp. 173-194. London: Bloomsbury Academic.

García Canclini, Néstor. 2014. Art Beyond Itself: Anthropology for a Society without a Story Line, trans. David Frye. Durham and London: Duke University Press.

Larkin, Brian 2018. Promising Forms: The Political Aesthetics of Infrastructure. In The Promise of Infrastructure. Nikhil Anand, Akhil Gupta and Hannah Appel, eds. Pp 175-202 Durham and London: Duke University Press.

Lash, Scott. 2007. Power after Hegemony: Cultural Studies in Mutation? Theory, Culture and Society 24(3): 55-78.

Levine, Caroline. 2015. Forms: Whole, Rhythm, Hierarchy, Network. Princeton and Oxford: Princeton University Press. 
Ludmer, Josefina. 2007. Literaturas postautónomas. Ciberletras 17. http://www.lehman.cuny.edu/ ciberletras/v17/ludmer.htm (accessed February 14, 2018).

Palmeiro, Cecilia. 2011. Desbunde y felicidad: de la cartonera a Perlongher. Buenos Aires: Título.

Papastergiadis, Nikos. 2014. A Breathing Space for Aesthetics and Politics: An Introduction to Jacques Rancière. Theory, Culture and Society 31(7-8): 5-26.

Piepmeier, Alison. 2009. Girl Zines: Making Media, Doing Feminism. New York: New York University Press.

Rancière, Jacques. 2004. The Politics of Aesthetics, trans. Gabriel Rockhill. London and New York: Continuum.

Rancière, Jacques. 2009. Aesthetics and its Discontents, trans. Steven Corcoran. Malden, MA: Polity Press.

Rosa, Lúcia. 2017. Vocabulario vivido. São Paulo: Dulcinéia Catadora.

Tunali, Tijen. 2015. Book Review. Néstor García Canclini. Art Beyond Itself: Anthropology for a Society Without a Story Line. Aesthetic Investigations 1(2): 336-338.

\section{NOTES}

1. This connotation stems from the fact that across Latin America books are extremely expensive, for example, the Blackwell Companion to Social Inequalities by Mary Romero and Eric Margolis (2005), costs more via the largest online Brazilian bookseller than a full month's minimum wage in São Paulo.

2. O ABRIGO E O TERRENO: arte e sociedade no Brasil I. Available online: https:// www.museudeartedorio.org.br/pt-br/exposicoes/o-abrigo-e-o-terreno (accessed 18 January, 2019).

3. Definition available online: https://www.lexico.com/en/definition/emulate (accessed 6 October 2019).

4. Definition available online: https://www.techopedia.com/definition/4787/emulation. (accessed 18 February 2019).

5. For example, the flights from Guadalajara to São Paulo for the encontro cost the equivalent of 284 days of a Mexican minimum wage; the equivalent period of minimum wage in the UK would be worth $£ 17,487$.

\section{ABSTRACTS}

This article puts forward a methodological pathway for work between anthropology and art that is premised on the relation between social and aesthetic form. It draws on the authors' work with cartonera publishers in Latin America, small community-based collectives whose members make low-cost books from recycled cardboard in an explicit attempt to make both the consumption and production of literature accessible to wider society. We begin by describing Dulcinéia Catadora, a cartonera publisher based in São Paulo that is the ethnographic focus of this article. 
We then present three theoretical propositions, which enable us to analyse not in isolation from, but rather in relation to, social and political processes, asking how ethnographic practice can intersect with aesthetics in a mode which goes beyond the illustrative. We conclude by proposing what we term a 'trans-formal' methodological approach based on a method of 'emulation', opening up new possibilities for research that is multi-disciplinary, transnational, horizontal and participatory.

Cet article propose une approche méthodologique centrée autour des sciences sociales et humaines afin d"étudier les relations entre formes sociales et esthétiques. Cette contribution est fondée sur le travail des éditeurs cartonera en Amérique Latine : il s'agit de petits collectifs dont les membres produisent des livres bons marchés à partir de papiers cartons, afin de rendre la production et la consultation de littérature accessible à un public plus large. Dans une première partie nous procédons à une description ethnographique de Dulcinéia Catadora, un éditeur de cartonera basé à São Paulo. En questionnant comment la pratique ethnographique peut s'entrecouper avec l'esthétique au-delà de l'illustratif, nous présentons par la suite trois propositions théoriques grâce auxquelles nous analysons cartonera dans ses interactions sociales et politiques. Nous proposons ainsi une approche 'trans-formale' qui est fondée sur l'émulation, et permet de nouvelles recherches pour une recherche pluridisciplinaire, transnationale, horizontale et participative.

Este artículo presenta una propuesta metodológica para el trabajo entre la antropología y las artes que se basa en la relación entre la forma social y la forma estética. Parte del trabajo de los autores con los editores cartonera en América Latina. Éstos son pequeños colectivos comunitarios cuyos miembros fabrican libros de bajo coste a partir de cartón reciclado en un intento explícito de hacer que el consumo y la producción de literatura sean accesibles para la sociedad en general. Comenzamos describiendo a Dulcinéia Catadora, una editora de cartonera de São Paulo que es el foco etnográfico de este artículo. Luego presentamos tres proposiciones teóricas que nos permiten analizar los procesos sociales y políticos no de manera aislada, sino más bien en relación, preguntando cómo la práctica etnográfica puede cruzarse con la estética en un modo que va más allá de lo ilustrativo. Concluimos proponiendo lo que llamamos un enfoque metodológico "trans-formal", basado en un método de "emulación", que abre nuevas posibilidades para una investigación multidisciplinaria, transnacional, horizontal y participativa.

\section{INDEX}

Keywords: aesthetics, politics, form, methodology, trans-formal, cartonera, Latin America Palabras claves: estética, política, metodología, trans-formal, cartonera, América Latina Mots-clés: esthétique, politique, forme, méthodologie, trans-formalisme, cartonera, Amérique latine

\section{AUTHORS}

\section{ALEX FLYNN}

University College London, Dept. of Anthropology

a.flynn@ucl.ac.uk

\section{LUCY BELL}

University of Surrey, School of Literature and Languages 
l.a.bell@surrey.ac.uk 